\title{
COMMUTING SUBSIDIES WITH TWO TRANSPORT MODES
}

\author{
RAINALD BORCK \\ MATTHIAS WREDE
}

CESIFO WORKING PAPER NO. 1972

CATEGORY 1: PubliC FinANCE

APRIL 2007
An electronic version of the paper may be downloaded
- from the SSRN website:
- from the RePEc website:
www.SSRN.com
- from the CESifo website:
www.RePEc.org
www.CESifo-group.de




\title{
COMMUTING SUBSIDIES WITH TWO TRANSPORT MODES
}

\begin{abstract}
We study a simple model of commuting subsidies with two transport modes. City residents choose where to live and which mode to use. When all land is owned by city residents, one group gains from subsidies what the other loses. With absentee landownership, city residents as a group gain at the expense of landowners. Subsidies toward different modes have different effects, however, for instance, in one case, rich automobile drivers suffer from transit subsidies, while poor transit users may benefit from subsidies to automobiles.

JEL Code: R14, R48.

Keywords: commuting subsidies, voting, monocentric city.

\author{
Rainald Borck \\ University of Munich \\ Department of Economics \\ Ludwigstr. $28 \mathrm{Vgb}$ \\ 80539 Munich \\ Germany \\ rainald.borck@Irz.uni-muenchen.de
}

\author{
RWTH Aachen University \\ Department of Business and Economics \\ Templergraben 64 \\ 52056 Aachen \\ Germany \\ mwr@fiwi.rwth-aachen.de
}

Matthias Wrede
\end{abstract}

April 10, 2007 


\section{Introduction}

We study the redistributive effects of commuting subsidies in a monocentric city with two income groups and two transport modes. City residents choose where to live and which transport mode to use. Subsidies then redistribute between city residents living at different distances from the city center, and between city residents and absentee landowners.

The paper uses a simplified version of Borck and Wrede [3], assuming fixed housing consumption. However, we extend the model by allowing for two transport modes. We thus combine the analysis of transport subsidies with the study of transport mode choice as in LeRoy and Sonstelie [9] and Sasaki [10]. ${ }^{1}$ This extension also allows us to introduce different subsidy rates for the different transport modes.

We find that with resident landownership, subsidies always redistribute between city residents (as long as mode choice is unaffected) and, therefore, one group gains what the other loses. With absentee landownership, city residents as a group generally benefit from commuting subsidies at the expense of landowners. In this case, when both groups use the same mode, they both benefit from subsidies to this mode. When the poor live in the city center and use public transport while the rich live in the suburbs and use cars, we find that subsidies to public transport hurt the rich, while the poor may benefit from subsidies to cars. We also examine a case with three distinct areas, where the rich use public transport in the center and cars in the suburbs, while the poor live between those groups and use public transport. Here, subsidizing public transit more heavily than cars hurts and subsidizing cars more heavily benefits the rich, while the effect on the poor is ambiguous.

In the next section, we introduce our model. We then study three distinct cases of residence patterns and mode choice: In section 3, both groups use public transit, in section 4 the poor use transit and the rich cars, and in section 5 , the rich use both modes (transit in the center and cars in the suburbs), while the poor use only transit. The last section concludes the paper.

\footnotetext{
${ }^{1}$ See also DeSalvo and Huq [7]. Brueckner and Selod [5] study a similar model where the speed of the (unique) transport system in a city is chosen endogenously. For a nontechnical discussion of some of these issues, see Borck [2].
} 


\section{The model}

We consider a simple model with two groups of individuals living in a monocentric city. The groups are denoted by $i=H, L$, and group $i$ has $n_{i}$ homogeneous members. We assume that group $H$ has high income and $L$ has low income, i.e. $y_{H}>y_{L}$, where $y_{i}$ is the income of a member of group $i$. Income consists of two components:

$$
y_{i}=w_{i}+\theta_{i} A L R
$$

where $w_{i}$ is the wage of a group $i$ individual, with $w_{H}>w_{L}$, and $\theta_{i}$ is the share of the average land rent $A L R$ accruing to group $i$ members.

Individuals live on plots of land of fixed size. Land consumption by a group $i$ member is $q_{i}$ with $q_{H} \geq q_{L}$, so the rich consume more land than the poor (see, e.g., de Bartolome and Ross [6]). All city residents commute to the CBD for work. There are two transport modes, denoted $A$ and $B$. For example, $A$ may be the automobile and $B$ the bus or some other form of public transport. Users of mode $j=A, B$ incur a fixed cost of $F_{j}$. Further, the variable round trip commuting cost for an individual of type $i$ living at $r \mathrm{~km}$ from the CBD is $\left[\left(1-s_{j}\right) t_{j}+\phi_{j} w_{i}\right] r$, where $t_{i}$ is the monetary value of the per-mile-commuting costs of mode $j, s_{j}$ the subsidy rate towards mode $j$, and $\phi_{j}$ is the time cost (the inverse of travel speed) of mode $j$.

Hence, the total cost of using mode $j$ at distance $r$ is $F_{j}+\left[\left(1-s_{j}\right) t_{j}+\phi_{j} w_{i}\right] r$. Mode $A$ has higher fixed cost but lower time costs: $F_{A}>F_{B}, \phi_{A}<\phi_{B}$. In addition we assume that for both groups, the variable cost of mode $A$ is lower than that of mode $B$ (see Sasaki $[10])$ :

$$
t_{A}+\phi_{A} w_{i}<t_{B}+\phi_{B} w_{i}
$$

We then get a group specific cutoff distance, $r_{i}^{*}, i=H, L$, where a member of group $i$ is just indifferent between using mode $A$ and $B$ :

$$
r_{i}^{*}=\frac{F_{A}-F_{B}}{\left(1-s_{B}\right) t_{B}-\left(1-s_{A}\right) t_{A}+\left(\phi_{B}-\phi_{A}\right) w_{i}} .
$$

Under the assumptions that the automobile has higher fixed costs but lower variable costs for both groups than the bus, $r_{i}^{*}>0, i=H, L$ so that close to the CBD individuals will commute by bus.

Since $w_{H}>w_{L}, r_{H}^{*}<r_{L}^{*}$. This implies that if at some distance $r$, the rich use the bus, so must the poor, and conversely, if at some $r$ the poor commute by car so do the rich. 
We assume that housing consumption does not enter utility. Therefore utility of an individual of type $i$ living $r \mathrm{~km}$ from the CBD if she uses mode $j$ equals consumption

$$
c_{i}^{j}=y_{i}-F_{j}-\left[\left(1-s_{j}\right) t_{j}+\phi_{j} w_{i}\right] r-T-R_{i} q_{i}, \quad \text { for } i=H, L \text { and } j=A, B .
$$

where $R$ is land rent and $T$ a lump sum tax.

Since each member of group $i$ must attain the same utility level, (3) implies the bid rent functions (i.e. the maximum rent an individual of group $i$ living at distance $r$ from the CBD who uses mode $j$ would be willing to pay):

$$
R_{i}^{j}=\frac{y_{i}-F_{j}-\left[\left(1-s_{j}\right) t_{j}+\phi_{j} w_{i}\right] r-T-c_{i}}{q_{i}}, \quad \text { for } i=H, L \text { and } j=A, B \text {. }
$$

The bid rent of group $i$ members is then defined as $R_{i}(r)=\max \left\{R_{i}^{A}, R_{i}^{B}\right\}$ and land rent at $r$ is $R(r)=\max \left\{0, R_{H}(r), R_{L}(r)\right\}$.

Suppose that both groups use the same transport mode. Then, the group with the steeper bid rent curve will live closer to the CBD. This implies that the rich live closer to the CBD than the poor if

$$
\frac{\left(1-s_{j}\right) t_{j}+\phi_{j} w_{H}}{q_{H}}>\frac{\left(1-s_{j}\right) t_{j}+\phi_{j} w_{L}}{q_{L}} \text { for } j=A, B .
$$

We will assume that this condition holds, which says that the arc income elasticity of housing consumption is less than the arc income elasticity of variable transport costs. See also LeRoy and Sonstelie [9], de Bartolome and Ross [6], and also Glaeser et al. [8] who argue that this is consistent with the available empirical evidence.

The city is linear and extends from the CBD, located at zero, to the urban fringe $\bar{r}=q_{H} n_{H}+q_{L} n_{L}$. Average land rent is

$$
A L R=\frac{1}{n_{H}+n_{L}} \int_{0}^{\bar{r}} R(r) d r .
$$

The government budget constraint simply states that total tax revenue must equal total subsidy disbursements, or the lump sum tax equals

$$
T=\frac{1}{n_{H}+n_{L}} \int_{0}^{\bar{r}} s^{*} t^{*} \frac{r}{q^{*}} d r,
$$

where the ${ }^{*}$ indicates that we consider only the group/mode with the highest bid rent at $r$. 
In equilibrium the city is divided into at most four areas, where each area is populated by members of one group only which all use the same transport mode (see LeRoy and Sonstelie [9] and Sasaki [10]). At one extreme, all rich and all poor use the same mode, while at the other extreme, each mode is used by all groups. In this paper, we will consider three specific examples with two or three different areas where in all examples the poor use the bus.

\section{Both groups commute by bus}

Suppose first that both groups use the same mode. Since fixed costs are positive, this means both groups commute by bus. The equilibrium in the city is characterized by the following equilibrium conditions:

$$
\begin{aligned}
R_{H}^{B}\left(r_{1}\right) & =R_{L}^{B}\left(r_{1}\right), \\
R_{L}^{B}(\bar{r}) & =0
\end{aligned}
$$

with $r_{1}=n_{H} q_{H}$ and $\bar{r}=n_{H} q_{H}+n_{L} q_{L}$. Equation (9) states that the bid rent of the outermost resident living at $\bar{r}$ just equals the agricultural rent which we normalize to zero. Equation (8) says that at the border between rich and poor, denoted $r_{1}$, rich and poor must be willing to pay the same amount per square meter land. Writing out the expression for $R_{L}(\bar{r})$, using $\bar{r}=n_{H} q_{H}+n_{L} q_{L}$, gives:

$$
R_{L}(\bar{r})=\frac{y_{L}-F_{B}-\left[\left(1-s_{B}\right) t_{B}+\phi_{B} w_{L}\right]\left(n_{L} q_{L}+n_{H} q_{H}\right)-T-c_{L}}{q_{L}} .
$$

Setting $R_{L}(\bar{r})=0$ gives the equilibrium utility of the poor

$$
c_{L}=y_{L}-F_{B}-\left[\left(1-s_{B}\right) t_{B}+\phi_{B} w_{L}\right]\left(n_{L} q_{L}+n_{H} q_{H}\right)-T .
$$

Using (11) together with $r_{1}=n_{H} q_{H}$ in (8) gives:

$$
\frac{\left[\left(1-s_{B}\right) t_{B}+\phi_{B} w_{L}\right] n_{H} q_{H}}{q_{L}}=\frac{y_{H}-F_{B}-\left[\left(1-s_{B}\right) t_{B}+\phi_{B} w_{H}\right] n_{L} q_{L}-T-c_{H}}{q_{H}}
$$

Substituting (11) and $r_{1}=n_{H} q_{H}$ into (4) and solving (12) gives the equilibrium utility level of the rich:

$$
c_{H}=y_{H}-F_{B}-\left[\left(1-s_{B}\right) t_{B}+\phi_{B} w_{H}\right] n_{H} q_{H}-\left[\left(1-s_{B}\right) t_{B}+\phi_{B} w_{L}\right] n_{L} q_{H}-T .
$$


Average variable transport costs net of subsidies are defined as

$$
A T C=\frac{1}{n_{H}+n_{L}} \int_{0}^{r_{1}} \frac{\left[\left(1-s_{B}\right) t_{B}+\phi_{B} w_{H}\right] r}{q_{H}} d r+\int_{r_{1}}^{\bar{r}} \frac{\left[\left(1-s_{B}\right) t_{B}+\phi_{B} w_{L}\right] r}{q_{L}} d r .
$$

Integrating (14) by parts yields

$$
A L R=A T C .
$$

That is in a linear city with linear transport cost, average land rent equals average total transport costs net of subsidies (Arnott and Stiglitz [1]). This holds regardless of the exact pattern of mode choice and land use.

Using the fact that boundaries are fixed and taking (14), (15) and (7) into account, we find immediately

$$
\frac{\partial A L R}{\partial s_{j}}=-\frac{\partial T}{\partial s_{j}}<0
$$

Subsidies reduce average land rent regardless of landownership. Furthermore, the sum of average land rent and lump sum tax is not affected by subsidies.

To see the reason behind this result, we use (11) and (13) in (4) to find

$$
\begin{aligned}
R_{H}(0) & =n_{L}\left[\left(1-s_{B}\right) t_{B}+\phi_{B} w_{L}\right]+n_{H}\left[\left(1-s_{B}\right) t_{B}+\phi_{B} w_{H}\right] \\
R_{L}\left(q_{H} n_{H}\right) & =n_{L}\left[\left(1-s_{B}\right) t_{B}+\phi_{B} w_{L}\right] .
\end{aligned}
$$

Thus, increasing $s_{B}$ decreases land rent both at the CBD and at the rich/poor border. Total land rent therefore falls. Subsidizing transport makes both groups' bid rents flatter. Since housing consumption is fixed and rent at the city border must be zero, this implies that aggregate land rent must fall. This is one of the clues to understanding the political support for commuting subsidies. Since they lead individuals to prefer locations farther from the center, total land rent falls, and rents fall most for those who live closest to the center. These are of course the individuals whom one would expect to lose from subsidies in purely fiscal terms.

Finally, we can calculate the lump sum tax and average land rent explicitly and substitute into (11) and (13). Doing so yields simple expressions for the effect of the subsidy on the utility of the rich and poor:

$$
\begin{aligned}
\frac{\partial c_{L}}{\partial s_{B}} & =\frac{\left\{\left[n_{H}+\left(1-\theta_{L}\right) n_{L} / 2\right] n_{L} q_{L}+\left[\left(1-\theta_{L}\right) n_{H} / 2-\theta_{L} n_{L}\right] n_{H} q_{H}\right\} t_{B}}{n_{L}+n_{H}} \\
\frac{\partial c_{L}}{\partial s_{B}} & =\frac{\left\{\left(1+\theta_{H}\right) n_{L}^{2} q_{L}-\left[\left(1-\theta_{H}\right) n_{L}+\left(1-\theta_{H}\right) n_{H} / 2+n_{L}^{2} / n_{H}\right] n_{H} q_{H}\right\} t_{B}}{n_{L}+n_{H}}
\end{aligned}
$$


Note that subsidies have no efficiency effects as long as they leave the type of equilibrium unaltered. The boundary between the rich and poor area is independent of subsidies, and we assume mode choice to be unaffected by the subsidy. Hence, small changes in subsidies only redistribute between both groups of commuters and landowners. Total welfare is

$$
W=n_{H} c_{H}+n_{L} c_{L}+\left[\left(1-\theta_{H}\right) n_{H}+\left(1-\theta_{L}\right) n_{L}\right] A L R .
$$

Hence:

$$
\frac{\partial W}{\partial s_{B}}=n_{H} \frac{\partial c_{H}}{\partial s_{B}}+n_{L} \frac{\partial c_{L}}{\partial s_{B}}+\left[\left(1-\theta_{H}\right) n_{H}+\left(1-\theta_{L}\right) n_{L}\right] \frac{\partial A L R}{\partial s_{B}}=0 .
$$

Commuters' gains equal landowners' losses. This is natural, for instance, Brueckner [4] found that commuting subsidies in a model like ours but with variable land consumption are inefficient. In our model with fixed land consumption, subsidies simply redistribute between commuters and landowners and have no efficiency consequences as long as mode choice is not affected. Therefore, this result also holds in the next subsection - where rich and poor used different modes - as long as subsidies do not affect mode choice.

We will now consider two polar cases of landownership more explicitly. The first case of interest is that of absentee landownership. Using $\theta_{L}=\theta_{H}=0$ we find

$$
\begin{array}{r}
\frac{\partial c_{L}}{\partial s_{B}}=\frac{\left[n_{H}^{2} q_{H} / 2+\left(n_{H}+n_{L} / 2\right) n_{L} q_{L}\right] t_{B}}{n_{L}+n_{H}} \\
\frac{\partial c_{H}}{\partial s_{B}}=\frac{\left\{\left[n_{L}\left(n_{L}+n_{H}\right)+n_{H}^{2} / 2\right] q_{H}-n_{L}^{2} q_{L}\right\} t_{B}}{n_{L}+n_{H}}
\end{array}
$$

Since $q_{H} \geq q_{L}$, we have:

Proposition 1 Suppose that rich and poor commute by bus and land is owned by absentee landowners. Then, both rich and poor benefit from a subsidy to public transport. The total gain to city residents equals the total loss to landowners.

Equations (23) and (24) show that both groups gain from the introduction of commuting subsidies. The poor have longer commutes and therefore benefit from commuting subsidies financed by head taxes in purely fiscal terms, while the rich pay more than they receive in subsidies. However, the rich incur a larger fall in land rent and the net effect on utility is therefore qualitatively the same for both groups.

We now consider resident landownership. In particular, suppose that both rich and poor receive an equal share of aggregate land rent, i.e. $\theta_{L}=\theta_{H}=1$. (22) shows that subsidies will either have no effect on utility or it will benefit one group of citizens at the 
expense of the other group. Residents as a group cannot gain from subsidies. This is shown also by Borck and Wrede [3] in the case with variable land consumption when the initial subsidy rate is zero. Here, it holds more generally. Simplifying (19) and (20), we get explicitly:

$$
\frac{\partial c_{L}}{\partial s_{B}}=-\frac{n_{H}}{n_{L}} \frac{\partial c_{H}}{\partial s_{B}}=\frac{\left(q_{L}-q_{H}\right) n_{L} n_{H} t_{B}}{n_{L}+n_{H}} .
$$

Therefore, we have the following result:

Proposition 2 Suppose that rich and poor commute by bus and land is owned by city residents in equal proportions. Suppose further that the rich consume more land than the poor. Then, increasing the level of subsidies benefits the rich at the expense of the poor.

\section{Poor commute by bus, rich by car}

The second case we consider is that where the poor live in the center and commute by bus, while the rich live in the suburbs and commute by car. LeRoy and Sonstelie [9] and Glaeser et al. [8] argue that the availability of fast but expensive transport modes was responsible for the suburbanization of wealthy city residents in the US.

At the border between the poor and rich, the poor bid rent function when they commute by bus must be steeper than the rich bid rent function when those use the car:

$$
\frac{\left(1-s_{B}\right) t_{B}+\phi_{B} w_{L}}{q_{L}}>\frac{\left(1-s_{A}\right) t_{A}+\phi_{A} w_{H}}{q_{H}} .
$$

We proceed like in the previous section, leaving out much of the detail, however. The equilibrium conditions are now

$$
R_{L}^{B}\left(r_{1}\right)=R_{H}^{A}\left(r_{1}\right), \quad \text { and } \quad R_{H}^{A}(\bar{r})=0
$$

Solving for the equilibrium utility of poor and rich gives:

$$
\begin{aligned}
c_{L} & =y_{L}-F_{B}-\left[\left(1-s_{B}\right) t_{B}+\phi_{B} w_{L}\right] n_{L} q_{L}-\left[\left(1-s_{A}\right) t_{A}+\phi_{A} w_{H}\right] n_{H} q_{L}-T \\
c_{H} & =y_{H}-F_{A}-\left[\left(1-s_{A}\right) t_{A}+\phi_{A} w_{H}\right]\left(n_{L} q_{L}+n_{H} q_{H}\right)-T .
\end{aligned}
$$

The head tax which satisfies the government budget is now

$$
T=\frac{s_{B} t_{B} n_{L}^{2} q_{L} / 2+s_{A} t_{A} n_{H}\left(n_{L} q_{L}+n_{H} q_{H} / 2\right)}{n_{L}+n_{H}}
$$


and average land rent

$$
A L R=\frac{\left[\left(1-s_{B}\right) t_{B}+\phi_{B} w_{L}\right] n_{L}^{2} q_{L} / 2+\left[\left(1-s_{A}\right) t_{A}+\phi_{A} w_{H}\right] n_{H}\left(n_{H} q_{H}+n_{L} q_{L} / 2\right)}{n_{L}+n_{H}} .
$$

Using (30) and (31) in (28) and (29) gives expressions for the utility levels as functions of the subsidy rates $s_{A}, s_{B}$.

Consider again the case of absentee landownership. We find

$$
\begin{aligned}
\frac{\partial c_{L}}{\partial s_{A}} & =\frac{\left(q_{L}-q_{H} / 2\right) n_{H}^{2} t_{A}}{n_{L}+n_{H}} \\
\frac{\partial c_{L}}{\partial s_{B}} & =\frac{\left(n_{L} / 2+n_{H}\right) n_{L} q_{L} t_{B}}{n_{L}+n_{H}} \\
\frac{\partial c_{H}}{\partial s_{A}} & =\frac{\left(n_{L}^{2} q_{L}+\left(n_{L}+n_{H} / 2\right) n_{H} q_{H}\right) t_{A}}{n_{L}+n_{H}} \\
\frac{\partial c_{H}}{\partial s_{B}} & =-\frac{n_{L}^{2} q_{L} / 2 t_{B}}{n_{L}+n_{H}}
\end{aligned}
$$

This is summarized as:

Proposition 3 Suppose that the poor live in the center and commute by bus, while the rich live in the suburbs and commute by car. If land ownership is absentee, subsidizing buses will benefit the poor and harm the rich, while subsidizing cars will benefit the rich. The poor benefit from subsidies to cars iff $q_{L}>q_{H} / 2$.

Each group benefits from a subsidy to its own mode, which is cross-subsidized by the other group. However, the proposition shows an asymmetry: the rich who live in the suburbs dislike subsidies to public transport, while the poor city residents may like subsidies to suburbian automobile users. This is because housing market pressure is relieved for the poor when the mode used by the rich is subsidized. When rich housing (and thus commuting distances) is not too large relative to the poor, this effect is large enough to compensate for the fiscal loss of the poor.

Second, we consider again full resident landownership. Again, subsidies redistribute between the rich and poor:

$$
\begin{aligned}
\frac{\partial c_{L}}{\partial s_{A}} & =\frac{n_{H}\left[\left(n_{L}-n_{H}\right) q_{L}+n_{H} q_{H}\right] t_{A}}{n_{L}+n_{H}}=-\frac{n_{H}}{n_{L}} \frac{\partial c_{H}}{\partial s_{A}} \\
\frac{\partial c_{L}}{\partial s_{B}} & =\frac{n_{L} n_{H} q_{L} t_{B}}{n_{L}+n_{H}}=-\frac{n_{H}}{n_{L}} \frac{\partial c_{H}}{\partial s_{B}}
\end{aligned}
$$

Thus, we have shown: 
Proposition 4 Suppose that the poor live in the center and commute by bus, while the rich live in the suburbs and commute by car. If land is owned by all city residents in equal proportions, subsidizing buses will benefit the poor and hurt the rich, while subsidizing cars will benefit the rich and hurt the poor.

\section{Poor bus users surrounded by rich commuters}

From the possible equilibria with three different areas we choose one where rich car drivers live in the outskirts of town. From our assumption (5) follows that the rich live close to the CBD where they use the bus and that the poor also drive by bus and live in the middle. In contrast to equilibria with only two areas, subsidies now have efficiency effects, since they affect modal choices and the residence patterns. For the sake of simplification, we assume equal lot sizes in this section, namely that $q_{H}=q_{L}=1$. Hence, only the efficient use of transport modes is at stake. The equilibrium is determined by

$$
R_{H}^{B}\left(r_{1}\right)=R_{L}^{B}\left(r_{1}\right), \quad R_{L}^{B}\left(r_{2}\right)=R_{H}^{A}\left(r_{2}\right), \quad \text { and } \quad R_{H}^{A}(\bar{r})=0,
$$

where $r_{1}$ is the boundary between rich and poor bus users, $r_{2}$ separates poor bus users and rich car drivers, and $\bar{r}=n_{H} q_{H}+n_{L} q_{L}$ is still the urban fringe. From these equilibrium conditions we immediately obtain the equilibrium utility for the rich:

$$
c_{H}=w_{H}+\theta_{H} A L R-T-F_{A}-\left[\left(1-s_{A}\right) t_{A}+\phi_{A} w_{H}\right]\left(n_{H} q_{H}+n_{L} q_{L}\right) .
$$

Using (39), in equilibrium the bid rent function of the rich for mode $j=A, B$ can be written as

$$
R_{H}^{j}(r)=\frac{F_{A}-F_{j}+\left[\left(1-s_{A}\right) t_{A}+\phi_{A} w_{H}\right]\left(n_{H} q_{H}+n_{L} q_{L}\right)-\left[\left(1-s_{j}\right) t_{j}+\phi_{j} w_{H}\right] r}{q_{H}} .
$$

Equation (39) allows to decompose the impact on utility of the rich when subsidies are altered. While a change in car subsidies alters utility according to

$$
\frac{\partial c_{H}}{\partial s_{A}}=\theta_{H} \frac{\partial A L R}{\partial s_{A}}-\frac{\partial T}{\partial s_{A}}+\left(n_{H} q_{H}+n_{L} q_{L}\right) t_{A},
$$

a change in the subsidy for public transport leads to

$$
\frac{\partial c_{H}}{\partial s_{B}}=\theta_{H} \frac{\partial A L R}{\partial s_{B}}-\frac{\partial T}{\partial s_{B}}
$$




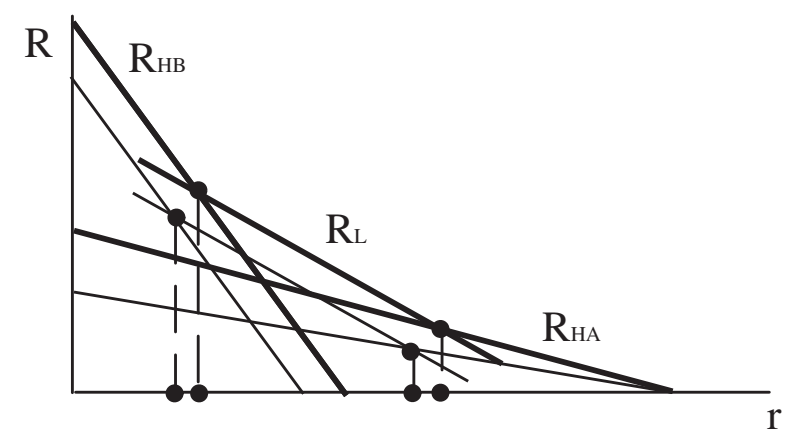

Figure 1: Higher subsidies for cars

Subsidies affect utility of this group only via the lump sum tax, via average land rent and - possibly - via monetary commuting costs at the urban fringe.

Finally, we can use equations (4), (38) and (40) to calculate the equilibrium bid rent of the poor

$$
R_{L}^{B}(r)=\frac{\left(1-s_{A}\right) t_{A}+\phi_{A} w_{H}}{q_{H}}\left(n_{H} q_{H}+n_{L} q_{L}-r_{2}\right)-\frac{\left(1-s_{B}\right) t_{B}+\phi_{B} w_{L}}{q_{L}}\left(r-r_{2}\right) .
$$

Since housing is fixed, subsidies do not change the size of the low-income area. They move both boundaries of the low-income area by the same amount either outwards or inwards. Using (40) and (43) we can calculate the impact of subsidy changes on bid rent curves. Consider first subsidies for cars going to the rich in the outermost area. From (40) follows that the bid rent function of rich car drivers becomes flatter and the bid rent function of rich bus drivers shifts downwards. (43) implies, that car subsidies do not affect the slope of poor citizens' bid rent curve. Taking into account that the size of the middle area does not change, the bid rent curve of poor residents shifts downwards (see figure 1). Since all bid rent curves move downwards, average land rent unambiguously falls. Car subsidies clearly hurt landowners, since lot sizes are fixed. It seems natural to think that the poor move inwards, more high income individuals use the car and less the bus. Indeed, this is what analytical results show:

$$
\frac{\partial n_{H}^{1}}{\partial s_{A}}=\frac{t_{A}\left[F_{B}-F_{A}+\phi_{B} n_{L}\left(w_{L}-w_{H}\right)\right]}{\left[\left(1-s_{A}\right) t_{A}+\phi_{A} w_{H}-\left(1-s_{B}\right) t_{B}-\phi_{B} w_{H}\right]^{2}}<0,
$$

where $n_{H}^{1}$ denotes the number of rich commuters living in the inner area.

In order to analyze subsidies for buses, we proceed like before. As can be seen from (40), subsidies for buses do not change the bid rent curve of rich car drivers, but flatten the 


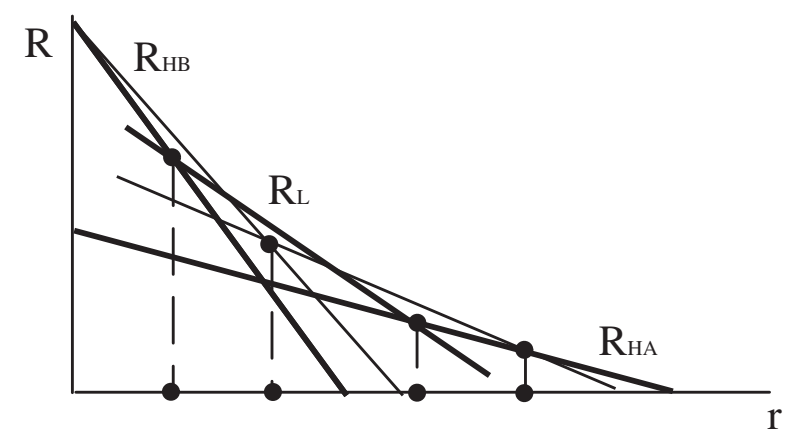

Figure 2: Higher subsidies for buses

bid rent curve of rich bus users. Bus subsidies change the position of the bid rent curve of poor commuters and also flatten the curve (see (43)). Again, we can use the fixed size of the middle area to conclude that poor residents move outwards in equilibrium (see figure 2 ). Less high income individuals live in the outer area and drive by car, some move to the central area and use the bus. The impact on average land rent and, thus, on landowners, is a priori unclear: while land rent in the inner central area and in the outer part of the middle area increase, land rent may decrease around the boundary between the inner and the middle area.

Next, we calculate how subsidies affect total welfare $W$ (of citizens and landowners):

$$
\frac{\partial W}{\partial s_{j}}=\frac{t_{j}\left(s_{j} t_{j}-s_{k} t_{k}\right)\left[F_{B}-F_{A}+\phi_{B} n_{L}\left(w_{L}-w_{H}\right)\right]^{2}}{\left[\left(1-s_{A}\right) t_{A}+\phi_{A} w_{H}-\left(1-s_{B}\right) t_{B}-\phi_{B} w_{H}\right]^{3}}, \quad \text { for } j, k=A, B, k \neq j .
$$

Due to our assumption (1) the denominator is negative when subsidies are sufficiently similar and do not reverse the order of variable transport costs. Independent of landownership, an increase in subsidy rate $s_{j}$ raises welfare if $s_{j} t_{j}<s_{k} t_{k}$. In order to rule out a distortion of transport mode choice, total subsidies per $\mathrm{km}$ should be equalized. Hence, we have shown:

Proposition 5 Suppose that the poor live in the middle area and commute by bus, while the rich live either in the suburbs and commute by car or close to the center and commute by bus. Suppose further that subsidies do not alter the relative size of variable transport costs. Then, narrowing the range of subsidies per $\mathrm{km}$ raises welfare.

Since our focus is on the distributional impact of commuting subsidies, we will rule out efficiency effects by analyzing small subsidy changes starting at $s_{B} t_{B}=s_{A} t_{A}$. Again we 
will consider two polar cases of landownership: absentee landowners $\left(\theta_{H}=\theta_{L}=0\right)$ and equal resident landownership $\left(\theta_{H}=\theta_{L}=1\right)$.

With absentee landownership subsidies have ambiguous effects.

$$
\begin{aligned}
\frac{\partial c_{L}}{\partial s_{B}} & =\frac{t_{B}\left[F_{B}-F_{A}+\phi_{B} n_{L}\left(w_{L}-w_{H}\right)\right]\left[F_{A}-F_{B}+\phi_{B}\left(n_{L}+2 n_{H}\right)\left(w_{L}-w_{H}\right)\right]}{2\left(n_{H}+n_{L}\right)\left[t_{B}+\phi_{B} w_{H}-t_{A}-\phi_{A} w_{H}\right]^{2}}, \\
\frac{\partial c_{H}}{\partial s_{B}} & =\frac{t_{B}\left[F_{B}-F_{A}+\phi_{B} n_{L}\left(w_{L}-w_{H}\right)\right]^{2}}{2\left(n_{H}+n_{L}\right)\left[t_{B}+\phi_{B} w_{H}-t_{A}-\phi_{A} w_{H}\right]^{2}}<0 .
\end{aligned}
$$

We skip analytical results for car subsidies, since the terms are rather cumbersome. Since efficiency effects are excluded by the starting condition $s_{B} t_{B}=s_{A} t_{A}$, which means that small subsidy changes leave welfare unaltered, in total residents gain from car subsidies at the expense of landowners (who - as we have shown before - are clearly hurt). Additional subsidies for cars increase taxes, but reduce land prices. However, (39) implies that the rich gain since transport costs for the outermost car driver are higher than average transport costs. Thus we have shown:

Proposition 6 Suppose that the poor live in the middle area and commute by bus, while the rich live either in the suburbs and commute by car or in the center and commute by bus. If landowners are absentee, subsidizing buses more heavily than cars will hurt the rich and subsidizing cars more heavily than buses will benefit the rich. The effects of subsidies on the poor are ambiguous.

Although some high income earners use buses, the rich are hurt by higher subsidies for public transport which lead to larger subsidy payments for more people with longer commutes. Hence, those high income commuters who still drive by car suffer from higher taxes without any benefit (as follows from (39)), since land rents are unaffected (see figure 2). The poor, however, gain from subsidies but suffer from higher taxes.

With resident landownership one income class wins exactly what the other loses (still assuming that initially $\left.s_{A} t_{A}=s_{B} t_{B}\right)$ :

$$
\begin{aligned}
\frac{\partial c_{L}}{\partial s_{A}} & =\frac{n_{H} \phi_{B} t_{A}\left(w_{H}-w_{L}\right)\left[F_{B}-F_{A}+\phi_{B} n_{L}\left(w_{L}-w_{H}\right)\right]}{\left(n_{H}+n_{L}\right)\left[t_{B}+\phi_{B} w_{H}-t_{A}-\phi_{A} w_{H}\right]^{2}}=-\frac{n_{H}}{n_{L}} \frac{\partial c_{H}}{\partial s_{A}}<0, \\
\frac{\partial c_{L}}{\partial s_{B}} & =-\frac{t_{B}}{t_{A}} \frac{\partial c_{L}}{\partial s_{A}}=-\frac{n_{H}}{n_{L}} \frac{\partial c_{H}}{\partial s_{B}}>0 .
\end{aligned}
$$

Thus, we have shown: 
Proposition 7 Suppose that the poor live in the middle area and commute by bus, while the rich live either in the suburbs and commute by car or in the center and commute by bus. If land is owned by all city residents in equal proportions, subsidizing buses more heavily than cars will benefit the poor at the expense of the rich, while subsidizing cars more heavily than buses will benefit the rich at the expense of the poor.

Since welfare remains unchanged, the opposing interests of landowning residents follows immediately from (22). Furthermore, it is not surprising that subsidizing cars benefits the rich, since the poor use only public transport.

\section{Conclusion}

The paper has studied the incidence of subsidies to urban public and private transport in a setting with two income groups and endogenous mode choice. As shown by, e.g., LeRoy and Sonstelie [9] and Sasaki [10], there are many possible equilibrium patterns, and we have only used three of them to illustrate the possibilities here. In a more general model with variable housing consumption, the analysis would get much more complicated but also more realistic. We believe that the approach should be fruitful to examine urban transport policies in a unified framework, where mode choice and residence patterns are determined simultaneously.

\section{References}

[1] R.J. Arnott, J.E. Stiglitz, Aggregate land rents and aggregate transport costs, Economic Journal 91 (1981), 331-347.

[2] R. Borck, The political economy of urban transit, forthcoming in OECD (ed.), Round Table on Privatisation and Regulation of Urban Transit, OECD, Paris (2007).

[3] R. Borck, M. Wrede, Political economy of commuting subsidies, Journal of Urban Economics 57 (2005), 478-499.

[4] J.K. Brueckner, Transport subsidies, system choice, and urban sprawl, Regional Science and Urban Economics 35 (2005), 715-733. 
[5] J.K. Brueckner, H. Selod, The political economy of urban transport system choice, Journal of Public Economics 90 (2006), 983-1005.

[6] C.A.M. de Bartolome, S.L. Ross, Who's in charge of the central city? The conflict between efficiency and equity in the design of a metropolitan area, Journal of Urban Economics 56 (2004), 458-483.

[7] J.S. DeSalvo, M. Huq, Income, residential location, and mode choice, Journal of Urban Economics 40 (1996), 84-99.

[8] E.L. Glaeser, M.E. Kahn, J. Rappaport, Why do the poor live in cities? The role of public transportation, Journal of Urban Economics, forthcoming.

[9] S.F. LeRoy and J. Sonstelie Paradise lost and regained: Transportation innovation, income, and residential location, Journal of Urban Economics 13 (1983), 67-89.

[10] K. Sasaki, Income class, modal choice, and urban spatial structure, Journal of Urban Economics 27 (1990), 323-343. 


\title{
CESifo Working Paper Series
}

\author{
(for full list see www.cesifo-group.de)
}

1908 Liliana E. Pezzin, Robert A. Pollak and Barbara S. Schone, Efficiency in Family Bargaining: Living Arrangements and Caregiving Decisions of Adult Children and Disabled Elderly Parents, February 2007

1909 Christian Keuschnigg and Soren Bo Nielsen, Self-Selection and Advice in Venture Capital Finance, February 2007

1910 Rune Jansen Hagen and Gaute Torsvik, Irreversible Investments, Dynamic Inconsistency and Policy Convergence, February 2007

1911 Eric A. Hanushek and Ludger Woessmann, The Role of School Improvement in Economic Development, February 2007

1912 Bernard M. S. van Praag, Perspectives from the Happiness Literature and the Role of New Instruments for Policy Analysis, February 2007

1913 Volker Grossmann and Thomas M. Steger, Growth, Development, and Technological Change, February 2007

1914 Margarita Katsimi and Thomas Moutos, Human Capital and the Feldstein-Horioka Puzzle, February 2007

1915 Oliver Roehn, Theo S. Eicher and Thomas Strobel, The Ifo Industry Growth Accounting Database, February 2007

1916 Ian Babetskii, Aggregate Wage Flexibility in Selected New EU Member States, February 2007

1917 Burkhard Heer, Alfred Maussner and Paul D. McNelis, The Money-Age Distribution: Empirical Facts and Limited Monetary Models, February 2007

1918 Yin-Wong Cheung, Menzie D. Chinn and Eijii Fujii, The Overvaluation of Renminbi Undervaluation, February 2007

1919 Jim Malley, Apostolis Philippopoulos and Ulrich Woitek, To React or Not? Fiscal Policy, Volatility and Welfare in the EU-3, February 2007

1920 Mattias Polborn, Competing for Recognition through Public Good Provision, February 2007

1921 Lars P. Feld and Benno Torgler, Tax Morale after the Reunification of Germany: Results from a Quasi-Natural Experiment, February 2007

1922 Robert S. Chirinko and Huntley Schaller, Fundamentals, Misvaluation, and Investment: The Real Story, February 2007 
1923 Benno Torgler and Friedrich Schneider, Shadow Economy, Tax Morale, Governance and Institutional Quality: A Panel Analysis, February 2007

1924 Adrian Pagan and M. Hashem Pesaran, On Econometric Analysis of Structural Systems with Permanent and Transitory Shocks and Exogenous Variables, February 2007

1925 Hans-Werner Sinn, The Welfare State and the Forces of Globalization, February 2007

1926 Michael Smart, Raising Taxes through Equalization, February 2007

1927 Øystein Foros, Kåre P. Hagen and Hans Jarle Kind, Price-Dependent Profit Sharing as an Escape from the Bertrand Paradox, February 2007

1928 Balázs Égert, Kirsten Lommatzsch and Amina Lahrèche-Révil, Real Exchange Rates in Small Open OECD and Transition Economies: Comparing Apples with Oranges?, February 2007

1929 Aleksander Berentsen and Cyril Monnet, Monetary Policy in a Channel System, February 2007

1930 Wolfgang Ochel, The Free Movement of Inactive Citizens in the EU - A Challenge for the European Welfare State?, February 2007

1931 James K. Hammitt and Nicolas Treich, Statistical vs. Identified Lives in Benefit-Cost Analysis, February 2007

1932 Wilhelm Kohler, The Bazaar Effect, Unbundling of Comparative Advantage, and Migration, February 2007

1933 Karsten Staehr, Fiscal Policies and Business Cycles in an Enlarged Euro Area, February 2007

1934 Michele Bernasconi and Paola Profeta, Redistribution or Education? The Political Economy of the Social Race, March 2007

1935 Axel Dreher, Martin Gassebner and Lars-H. R. Siemers, Does Terror Threaten Human Rights? Evidence from Panel Data, March 2007

1936 Naércio Aquino Menezes Filho and Marc-Andreas Muendler, Labor Reallocation in Response to Trade Reform, March 2007

1937 Gebhard Flaig and Timo Wollmershaeuser, Does the Euro-zone Diverge? A Stress Indicator for Analyzing Trends and Cycles in Real GDP and Inflation, March 2007

1938 Michael Funke and Michael Paetz, Environmental Policy Under Model Uncertainty: A Robust Optimal Control Approach, March 2007

1939 Byeongchan Seong, Sung K. Ahn and Peter A. Zadrozny, Cointegration Analysis with Mixed-Frequency Data, March 2007 
1940 Monika Bütler and Michel André Maréchal, Framing Effects in Political Decision Making: Evidence from a Natural Voting Experiment, March 2007

1941 Giacomo Corneo and Olivier Jeanne, A Theory of Tolerance, March 2007

1942 Qing Hong and Michael Smart, In Praise of Tax Havens: International Tax Planning and Foreign Direct Investment, March 2007

1943 Yin-Wong Cheung, Dickson Tam and Matthew S. Yiu, Does the Chinese Interest Rate Follow the US Interest Rate?, March 2007

1944 Panu Poutvaara and Mikael Priks, Unemployment and Gang Crime: Could Prosperity Backfire?, March 2007

1945 Burkhard Heer, On the Modeling of the Income Distribution Business Cycle Dynamics, March 2007

1946 Christoph A. Schaltegger and Lars P. Feld, Are Fiscal Adjustments less Successful in Decentralized Governments?, March 2007

1947 Giovanni Facchini, Marcelo Olarreaga, Peri Silva and Gerald Willmann, Substitutability and Protectionism: Latin America's Trade Policy and Imports from China and India, March 2007

1948 C. Mirjam van Praag and Bernard M. S. van Praag, The Benefits of Being Economics Professor A (and not Z), March 2007

1949 Astrid Hopfensitz and Frans van Winden, Dynamic Choice, Independence and Emotions, March 2007

1950 Guglielmo Maria Caporale and Luis A. Gil-Alana, A Multivariate Long-Memory Model with Structural Breaks, March 2007

1951 Mattias Ganslandt and Keith E. Maskus, Wholesale Price Discrimination and Parallel Imports, March 2007

1952 Michela Redoano, Fiscal Interactions Among European Countries. Does the EU Matter?, March 2007

1953 Stefan C. Wolter, Rémy Hübschi and Matthias Müller, Push or Pull? An Empirical Analysis of the Demand for Individual Project Grants from the Swiss National Science Foundation, March 2007

1954 Scott Alan Carson, African-American and White Inequality in the American South: Evidence from the $19^{\text {th }}$ Century Missouri State Prison, March 2007

1955 Peter Egger, Marko Koethenbuerger and Michael Smart, Do Fiscal Transfers Alleviate Business Tax Competition? Evidence from Germany, March 2007

1956 Panu Poutvaara and Lars-H. R. Siemers, Smoking and Social Interaction, March 2007 
1957 Stephan Danninger and Fred Joutz, What Explains Germany's Rebounding Export Market Share?, March 2007

1958 Stefan Krasa and Mattias Polborn, Majority-efficiency and Competition-efficiency in a Binary Policy Model, March 2007

1959 Thiess Buettner and Georg Wamser, Intercompany Loans and Profit Shifting Evidence from Company-Level Data, March 2007

1960 Per Pettersson-Lidbom and Mikael Priks, Behavior under Social Pressure: Empty Italian Stadiums and Referee Bias, April 2007

1961 Balázs Égert and Carol S. Leonard, Dutch Disease Scare in Kazakhstan: Is it real?, April 2007

1962 Paul De Grauwe and Pablo Rovira Kaltwasser, Modeling Optimism and Pessimism in the Foreign Exchange Market, April 2007

1963 Volker Grossmann and Thomas M. Steger, Anti-Competitive Conduct, In-House R\&D, and Growth, April 2007

1964 Steven Brakman and Charles van Marrewijk, It’s a Big World After All, April 2007

1965 Mauro Ghinamo, Paolo M. Panteghini and Federico Revelli, FDI Determination and Corporate Tax Competition in a Volatile World, April 2007

1966 Inés Macho-Stadler and David Pérez-Castrillo, Optimal Monitoring to Implement Clean Technologies when Pollution is Random, April 2007

1967 Thomas Eichner and Ruediger Pethig, Efficient $\mathrm{CO}_{2}$ Emissions Control with National Emissions Taxes and International Emissions Trading, April 2007

1968 Michela Redoano, Does Centralization Affect the Number and Size of Lobbies?, April 2007

1969 Christian Gollier, Intergenerational Risk-Sharing and Risk-Taking of a Pension Fund, April 2007

1970 Swapan K. Bhattacharya and Biswa N. Bhattacharyay, Gains and Losses of India-China Trade Cooperation - a Gravity Model Impact Analysis, April 2007

1971 Gerhard Illing, Financial Stability and Monetary Policy - A Framework, April 2007

1972 Rainald Borck and Matthias Wrede, Commuting Subsidies with two Transport Modes, April 2007 